\title{
Early Osteological Development of Larvae and Juveniles in Red Spotted Grouper, Epinephelus akaara (Pisces: Serranidae)
}

\author{
Jong Youn Park ${ }^{1}$, Kyeong Ho Han ${ }^{2}$, Jae Kwon Cho ${ }^{1}$, Jeong In Myeong ${ }^{1}$ and ${ }^{\dagger} J_{a e}$ Min Park ${ }^{3}$ \\ ${ }^{I}$ Aquaculture Management Division, Aquaculture Research Institute, NIFS, Busan 46083, Korea \\ ${ }^{2}$ Chonnam National University, Department of Aqualife Science, Yeosu 59626, Korea \\ ${ }^{3}$ Gyeongsangbuk-do Native Fish Business Center, Uiseong 37366, Korea
}

\begin{abstract}
We observed the osteological development of larval and juvenile red spotted grouper (Epinephelus akaara) in order to generate data for the assessment of skeletal deformities and to inform phylogenetic systematics research. Larvae and juveniles were obtained from a aquafarm in Muan-gun, Jeolla-namdo Province, Korea. The average water temperature at the time of breeding was $23.0^{\circ} \mathrm{C}$ and average water salinity was 33.0 psu. Freshly hatched fish larvae had not undergone any ossification, but ossification of the parasphenoid bone, which forms the base of the cranium, occurred as the juveniles reached an average body length (BL) of $2.49 \mathrm{~mm}$. At the same time, ossification of the preopercle and opercle occurred in the operculum, and ossification of the maxilla, which forms the upper jaw, and the dentary bones, which form the lower jaw, began. In addition, ossification of the vertebra occurred by formation of 7 vertebral centra and the neural spine in the abdominal vertebra. When the juveniles reached an average (BL) of $5.22 \mathrm{~mm}$, ossification of the nasal, lateral ethmoid, and alisphenoid bones occurred in the cranium; ossification of the endopterygoid and metapterygoid bones began in the palatine region; and ossification of the hypohyal and interhyal bones occurred in the hyoid arch. At an average (BL) of $20.9 \mathrm{~mm}$, ossification of the basisphenoid bone in the cranium and the suborbital bone in the orbital region occurred. Ossification of the vertebra then occurred by the formation of long pairs of ribs from the third to the ninth abdominal vertebrae, completing osteological development.
\end{abstract}

Key words : Epinephelus akaara, Juveniles, Larvae, Osteological development, Ossification, Red spotted grouper

\section{INTRODUCTION}

In order to improve the breeding and hatchery production of fishes, it is necessary to study the osteological development of fish larvae and juveniles so that early-stage skeletal deformities in hatchery fish may be identified and controlled. Such data can aid not only in species identification but in recognition of the osteological characteristics of adult fish, through in-depth and systematic studies (Koumoundouros et al., 1997a,b ${ }^{2}$; Park et al., 2014; Park et al., 2015b). Moreover, as fish undergo extreme morphological, physiological, and behavioral changes before metamorphosis from the larval to the juvenile stage, detailed knowledge of the osteological development can ensure that the best techniques are adopted for breeding and hatchery operations (Koumoundouros et al., 1999).

\footnotetext{
Manuscript received April 01, 2016, Received in revised form April 06, 2016, Accepted April 10, 2016

† Corresponding Author: Jae Min Park, Gyeongsangbuk-do Native Fish Business Center, Uiseong 37366, Korea. Tel. : +82-54-830-8833, Fax : +82-54830-8809, E-mail : jm1090@korea.kr

This is an Open Access article distributed under the terms of the Creative Commons Attribution Non-Commercial License (http:// creativecommons.org/licenses/by-nc/3.0) which permits unrestricted non-commercial use, distribution, and reproduction in any medium, provided the original work is properly cited.
} 
Red spotted grouper (Epinephelus akaara) belongs to the order Perciformes, family Serranidae. It is found along the southern coast of Korea, including around Jeju Island and near Japan, China, and Taiwan (Kim et al., 2005). Fish species belonging to the Serranidae family have high commercial value; therefore, many studies have examined their ecology and sought to develop good techniques to breed and rear them in hatcheries (Park et al., 2016b, c). Studies of red spotted grouper explored maturation and sex reversal (Lee et al., 1998), prey (Lee \& Hur, 1998), feeding period (Lee \& Hur, 1997), changes in egg quality (Lee et al., 1997), spawning behavior and early life history (Ukawa \& Higuchi, 1966), and egg development and morphological development of larvae and juveniles (Park et al., 2016a). The osteological development of fish has been studied in spotted sea bass (Lateolabrax maculatus), yellowbarred red rockfish (Sebastiscus tertius), Japanese red rockfish (Sebastes inermis), Japanese halfbeak (Hyporhamphus sajori), golden mandarin fish (Siniperca scherzeri), and convict grouper (E. septemfasciatus) Resferences. However, studies on osteological development in red spotted grouper larvae and juveniles have not been conducted. Therefore, it is necessary to gather basic data on skeletal deformities that frequently occur during breeding and growth in hatcheries (Kim et al., 1993; Han et al., 2001; Lee et al., 2001; Myoung et al., 2001; Kang et al., 2012; Park et al., 2015b).

Recent studies on breeding and hatchery technology for fish species in the Serranidae family have shown that the biggest problem is skeletal deformities which occur during cultivation. The same phenomenon occurs in convict groupers, which belong to the same family. Accordingly, in the present study, we observed the osteological development of red spotted grouper larvae and juveniles to obtain basic data on development and deformities for use in phylogenetic systematics research and to aid in species identification of larvae and juveniles.

\section{MATERIALS AND METHODS}

\section{Rearing of larvae and juveniles}

Red spotted grouper larvae and juveniles were obtained in June 2015 from artificially inseminated eggs spawned by a female fish at an indoor hatchery in Muan-gun, South Jeolla Province, Korea. The larvae were hatched in a 25 ton circular water tank ( $8 \mathrm{~m}$ diameter $\times 10 \mathrm{~m}$ height $)$ and cultivated under still-water conditions for up to 14 days after hatching with weak aeration. From 35 days after hatching, the juveniles were cultivated in a running water system. The temperature range during cultivation was $21.5 \sim 24.5^{\circ} \mathrm{C}$ (mean $23.0 \pm 1.5^{\circ} \mathrm{C}$ ), while the salinity was 32.5 33.5 psu (mean $33.0 \mathrm{psu}$ ). Food was provided in the form of 10 15 individuals per $\mathrm{mL}$ of Brachionus rotundiformis from 3 to 34 days after hatching; a mixture of 10 20 individuals per mL of Artemia nauplii from 34 to 46 days after hatching; and initial mixed feed from 46 days after hatching.

\section{Sampling and skeletal staining}

Immediately after hatching, 5 individuals were randomly collected every day. The samples were fixed in 5\% neutral formalin and stained according to the double staining method by Walker \& Kimmel (2007), then preserved in $0.1 \%$ $\mathrm{KOH}$ and 50\% glycerol. Stained samples were observed under a stereo microscope (Nikon SMZ800, Japan) and sketched accordingly. Identification of each skeletal component of larvae and juveniles followed Park et al. (2015b).

\section{RESULTS}

Observations on the osteological development of red spotted grouper larvae and juveniles were made following the division of the skeletal structure into cranium, visceral skeleton, vertebrae, pectoral girdle bones, caudal skeleton, fins, and pterygiophores. 
Early Osteological Development of Larvae and Juveniles in Red Spotted Grouper, Epinephelus akaara (Pisces: Serranidae)

\section{Cranial skeleton}

The cranial skeleton consisted of the cranium and visceral skeleton. The osteological development process according to growth stages was as follows (Fig. 1, Table 1 and 2).

Freshly hatched fish larvae had not undergone any ossification, but ossification of the parasphenoid bone, which forms the base of the cranium, occurred as the juveniles reached an average body length (BL) of $2.49 \mathrm{~mm}$. In addition, ossification of the preopercle and opercle occurred in the operculum, and ossification of the maxilla, which forms the upper jaw, and the dentary bones, which form the lower jaw, began (Fig. 1A).

When the juveniles reached an average (BL) of $3.44 \mathrm{~mm}$, ossification of the premaxillary in the upper jaw and articular and angular bones in the lower jaw occurred, while ossification of the epihyal and 4 branchiostegal rays in the hyoid arch and hyomandibular bone in the palatine region occurred (Fig. 1B).

When the juveniles reached an average (BL) of $3.98 \mathrm{~mm}$, ossification of the frontal and basioccipital bones in the cranium and periorbital/lacrimal bone in the orbital region took place. Ossification of the sphenotic and pterotic bones occurred above the hyomandibular bone, while ossification of the ectopterygoid, palatine, quadrate, and sympletic bones in the palatine region and interopercle and subopercle bones in the operculum also occurred (Fig. 1C).

When the juveniles reached an average (BL) of $5.22 \mathrm{~mm}$, ossification of the nasal, lateral ethmoid, alisphenoid, parietal, prootic, epiotic, and supraoccipital bones occurred in the cranium, while ossification of the endopterygoid and metapterygoid bones began in the palatine region and ossification of the hypohyal and interhyal bone occurred in the hyoid $\operatorname{arch}($ Fig. 1D).

When the juveniles reached an average (BL) of $14.9 \mathrm{~mm}$, ossification of the exoccipital, opisthotic, and mesethmoid bones occurred in the cranium, while ossification of the supramaxillary bone occurred in the jaw (Fig. 1E).
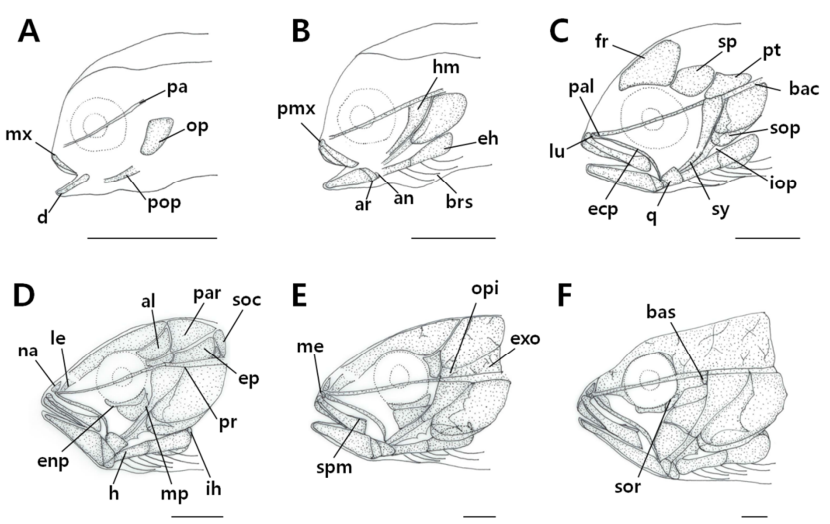

Fig. 1. Development of the cranium and visceral skeleton in red spotted grouper, Epinephelus akaara. (A) $2.49 \mathrm{~mm}$ in body length (BL); (B) $3.44 \mathrm{~mm}$ in BL; (C) $3.98 \mathrm{~mm}$ in $\mathrm{BL}$; (D) $5.22 \mathrm{~mm}$ in $\mathrm{BL}$; (E) 14.9 $\mathrm{mm}$ in BL; (F) $20.9 \mathrm{~mm}$ in BL. al, alisphenoid; an, angular; ar, articular; bac, basioccipital; bas, basisphenoid; brs, branchiostegal rays; d, dentary; ecp, ectopterygoid; eh, epihyal; ep, epiotic; enp, endopterygoid; exo, exoccipital; fr, frontal; h, hypohyal; hm, hyomandibular; ih, interhyal; iop, interopercle; le, lateral ethmoid; lu, periorbital/lacrimal; me, mesethmoid; mp, metapterygoid; mx, maxillary; na, nasal; op, opercle; opi, opisthotic; pa, parasphenoid; pal, palatine; par, parietal; pt, pterotic; pop, preopercle; pr, prootic; pmx, premaxillary; q, quadrate; soc, supraoccipital; sp, sphenotic; sop, subopercle; sor, suborbital; spm, supramaxillary; sy, sympletic. Scale bars $=0.5 \mathrm{~mm}$.

When the juveniles reached an average (BL) of $20.9 \mathrm{~mm}$, ossification of the basisphenoid bone in the cranium and the suborbital bone in the orbital region occurred, which completed the skeletal structural ossification process (Fig. 1F).

\section{Caudal skeleton}

The caudal skeleton was composed of a caudal complex consisting of vertebrae and bone fragments (Fig. 2, Table 1). No ossification had occurred at all when individuals had an average body length of $2.49 \mathrm{~mm}$ and the urostyle had a curvature of $45^{\circ}$ (Fig. 2A).

At an average (BL) of $3.44 \mathrm{~mm}$, ossification of the 
JY Park, KH Han, JK Cho, JI Myeong, JM Park

Table 1. Development of the cranium and visceral skeleton in red spotted grouper, Epinephelus akaara

\begin{tabular}{|c|c|c|c|c|c|c|c|c|c|c|c|}
\hline \multirow{2}{*}{$\begin{array}{l}\text { Skeletal } \\
\text { elements }\end{array}$} & \multicolumn{11}{|c|}{ Body length (mm) } \\
\hline & 2.49 & 3.44 & 3.98 & 4.83 & 5.22 & 8.84 & 10.2 & 12.8 & 14.9 & 18.5 & 20.9 \\
\hline \multicolumn{12}{|l|}{ Cranium } \\
\hline \multicolumn{12}{|l|}{ Parasphenoid } \\
\hline \multicolumn{12}{|l|}{ Supraoccipital } \\
\hline \multicolumn{12}{|l|}{ Epiotic } \\
\hline \multicolumn{12}{|l|}{ Alisphenoid } \\
\hline \multicolumn{12}{|l|}{ Parietal } \\
\hline \multicolumn{12}{|l|}{ Prootic } \\
\hline \multicolumn{12}{|l|}{ Basioccipital } \\
\hline \multicolumn{12}{|l|}{ Sphenotic } \\
\hline \multicolumn{12}{|l|}{ Pterotic } \\
\hline \multicolumn{12}{|l|}{ Frontal } \\
\hline \multicolumn{12}{|l|}{ Lateral ethmoid } \\
\hline \multicolumn{12}{|l|}{ Nasal } \\
\hline \multicolumn{12}{|l|}{ Exoccipital } \\
\hline \multicolumn{12}{|l|}{ Opisthotic } \\
\hline \multicolumn{12}{|l|}{ Mesethmoid } \\
\hline \multicolumn{12}{|l|}{ Basisphenoid } \\
\hline \multicolumn{12}{|l|}{ Orbital region } \\
\hline \multicolumn{12}{|l|}{ Suborbital } \\
\hline \multicolumn{12}{|l|}{ Periorbital } \\
\hline \multicolumn{12}{|l|}{ Hyoid arch } \\
\hline \multicolumn{12}{|l|}{ Epihyal } \\
\hline \multicolumn{12}{|l|}{ Branchiostegal } \\
\hline \multicolumn{12}{|l|}{ Hypohyal } \\
\hline Interhyal & & & & & & & & & & & \\
\hline
\end{tabular}


Early Osteological Development of Larvae and Juveniles in Red Spotted Grouper, Epinephelus akaara (Pisces: Serranidae)

Table 1. Continued

Skeletal

\begin{tabular}{lllllllllll}
\multicolumn{10}{c}{ Body length $(\mathrm{mm})$} \\
\hline 2.49 & 3.44 & 3.98 & 4.83 & 5.22 & 8.84 & 10.2 & 12.8 & 14.9 & 18.5 & 20.9
\end{tabular}

\section{Palate}

elements

Metapterygoid

Palatine

Ectopterygoid

Sympletic

Endopterygoid

Hyomandibular

Quadrate

\section{Opercular}

Opercle

Preopercle

Interopercle

Subopercle

\section{Jaw bone}

Maxillary

Premaxillary

Dentary

Supramaxillary

Angular

Articular

vertebrae had occurred, some ossification of the urostyle had occurred, and ossification of 5 hypural bones had occurred (Fig. 2B)

At an average (BL) of $3.98 \mathrm{~mm}$, ossification of the neural and hemal spines began, and ossification of a single parhypural bone and caudal bony plate on the upper part of the urostyle had occurred (Fig. 2C).
At an average (BL) of $5.22 \mathrm{~mm}$, ossification of the first epural bone had taken place, while ossification of uroneural bone occurred on the end of the urostyle and the fifth hypural bone (Fig. 2D).

At an average (BL) of $14.9 \mathrm{~mm}$, ossification of the second epural bone had occurred (Fig. 2E). When the average (BL) reached $20.9 \mathrm{~mm}$, ossification of the third epural bone had 


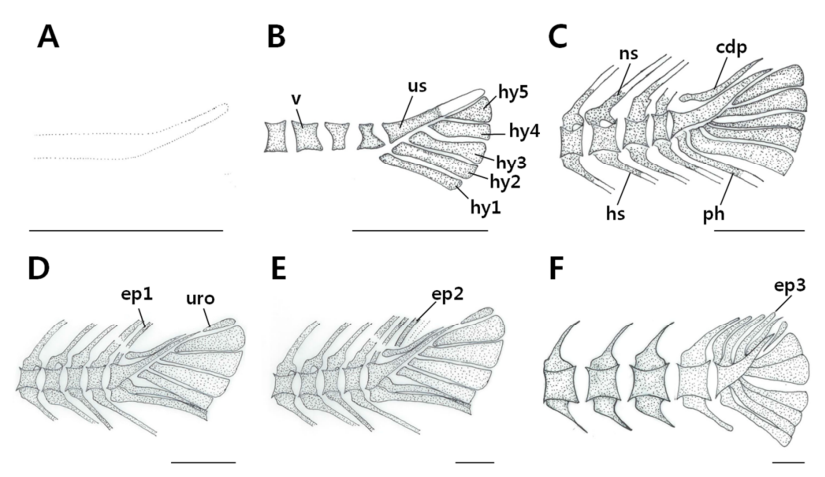

Fig. 2. Development of the caudal skeleton in red spotted grouper, Epinephelus akaara. (A) $2.49 \mathrm{~mm}$ in body length (BL); (B) $3.44 \mathrm{~mm}$ in BL; (C) $3.98 \mathrm{~mm}$ in BL; (D) $5.22 \mathrm{~mm}$ in BL; (E) $14.9 \mathrm{~mm}$ in $\mathrm{BL}$; (F) $20.9 \mathrm{~mm}$ in BL. cbp, caudal bony plate; ep, epural; hs, hemal spine; hy, hypural; ns, neural spine; ph, parhypural; uro, uroneural; us, urostyle; v, vertebrae. Scale bars $=0.5 \mathrm{~mm}$.

occurred, at which point the ossification process was complete and the fish was an adult (Fig. 2F).

\section{Pectoral girdle bones}

The pectoral girdle bone, which supports the pectoral fin, supports several membranous bones and is joined to the cranium by the posttemporal bone (Fig. 3, Table 2).

At an average (BL) of $2.49 \mathrm{~mm}$, ossification of the cleithrum began (Fig. 3A). At an average (BL) of $3.44 \mathrm{~mm}$, ossification of the supracleithrum occurred on the upper part of the cleithrum, which joined with the posttemporal bone, and ossification of the ventral post cleithrum also occurred (Fig. 3B). When individuals reached an average (BL) of $3.98 \mathrm{~mm}$, ossification of the first ventral post cleithrum began (Fig. 3C). When they reached an average (BL) of $5.22 \mathrm{~mm}$, ossification of the coracoids and supraposttemporal bones occurred and the pectoral fin rays differentiated (Fig. 3D). At an average (BL) of $14.9 \mathrm{~mm}$, ossification of the scapula and 4 actinost (radial) bones occurred, which completed the cleithrum development (Fig. 3E).
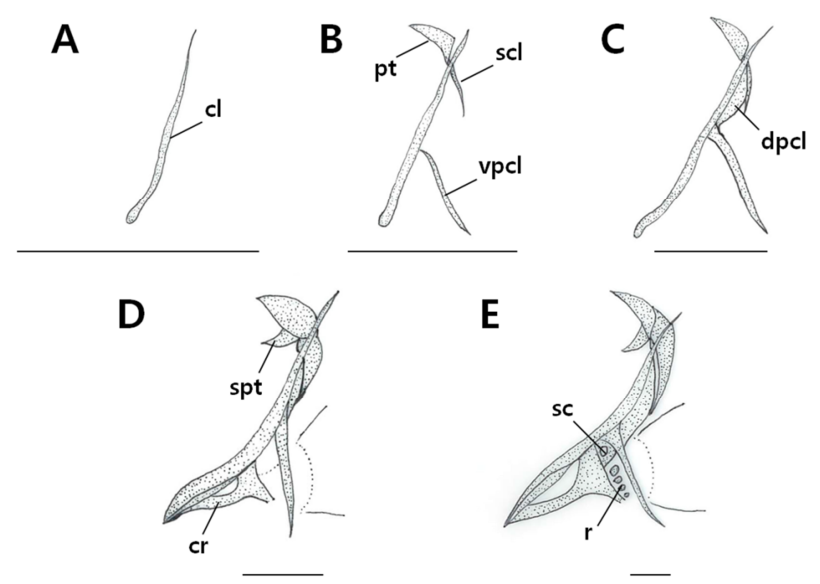

Fig. 3. Development of the pectoral girdle bone in red spotted grouper, Epinephelus akaara. (A) 2.49 $\mathrm{mm}$ in body length (BL); B: $3.44 \mathrm{~mm}$ in BL; (C) $3.98 \mathrm{~mm}$ in BL; (D) $5.22 \mathrm{~mm}$ in BL; (E) $14.9 \mathrm{~mm}$ in BL. cl, cleithrum; cr, coracoid; dpcl, dorsal post cleithrum; pt, posttemporal; r, radial; sc, scapula; scl, supracleithrum; spt, supraposttemporal; vpcl, ventral post cleithrum. Scale bars $=0.5 \mathrm{~mm}$.

\section{Vertebrae}

The ossification process of the vertebrae occurred as follows (Fig. 4, Table 3). When individuals reached an average (BL) of $2.25 \mathrm{~mm}$, ossification of the abdominal vertebra had not occurred and the urostyle showed a curvature of $45^{\circ}$ (Fig. 4A). At an average (BL) of $2.49 \mathrm{~mm}$, ossification of 7 vertebral centra and the neural spine began in the abdominal vertebra (Fig. 4B). At an average (BL) of $3.44 \mathrm{~mm}$, the number of ossified centra in the abdominal vertebra increased to 9, and ossification of 6 caudal vertebrae, together with the neural and hemal spines, occurred (Fig. 4C). At an average (BL) of $3.98 \mathrm{~mm}$, the number of ossified centra in the abdominal vertebra increased to 13 and ossification of the urostyle began, while parapophyses were formed from the first to the ninth abdominal vertebrae (Fig. 4D). At an average (BL) of 18.5 $\mathrm{mm}$, the number of centra increased to 15 (Fig. 4E), and at $20.9 \mathrm{~mm}$, ossification of the long pairs of 7 ribs occurred 
Early Osteological Development of Larvae and Juveniles in Red Spotted Grouper, Epinephelus akaara (Pisces: Serranidae)

Table 2. Development process of the pectoral girdle bone and caudal skeleton in red spotted grouper, Epinephelus akaara

\begin{tabular}{|c|c|c|c|c|c|c|c|c|c|c|c|}
\hline \multirow{2}{*}{$\begin{array}{l}\text { Skeletal } \\
\text { elements }\end{array}$} & \multicolumn{11}{|c|}{ Body length (mm) } \\
\hline & 2.49 & 3.44 & 3.98 & 4.83 & 5.22 & 8.84 & 10.2 & 12.8 & 14.9 & 18.5 & 20.9 \\
\hline
\end{tabular}

\section{Pectoral girdle}

Cleithrum

Dorsal post cleithrum

Ventral post cleithrum

Supracleithrum

Posttemporal

Supraposttemporal

Coracoid

Scapula

Actinost (radial)

\section{Caudal skeleton}

Urostyle

Hypural (first-fifth)

Parhypural

Epural (first)

(second)

(third)

Uroneural

Caudal bony plate

from the third to the ninth abdominal vertebrae (Fig. 4F).

\section{Fins and pterygiophores}

The ossification processes of the interneural spine, which supports the dorsal and other fins, as well as the pterygiophore and interhemal spine, which supports the anal fin, occurred as follows (Fig. 4, Table 3). The number of rays in the anal fin reached a fixed number on the $46^{\text {th }}$ day after hatching, at an average (BL) of $20.9 \mathrm{~mm}$, at which time the development of the procurrent rays was complete, with $8 \sim 9$ on top and $9 \sim 10$ on the bottom. On the $15^{\text {th }}$ day after hatching, when the average body length was $3.98 \mathrm{~mm}$, the second fin spine grew longer than the first fin spine. The fin spines shortened to display a form similar to that of an adult fish on the $46^{\text {th }}$ day after hatching, at an average (BL) of $20.9 \mathrm{~mm}$. A pair of rays appeared on the 
A
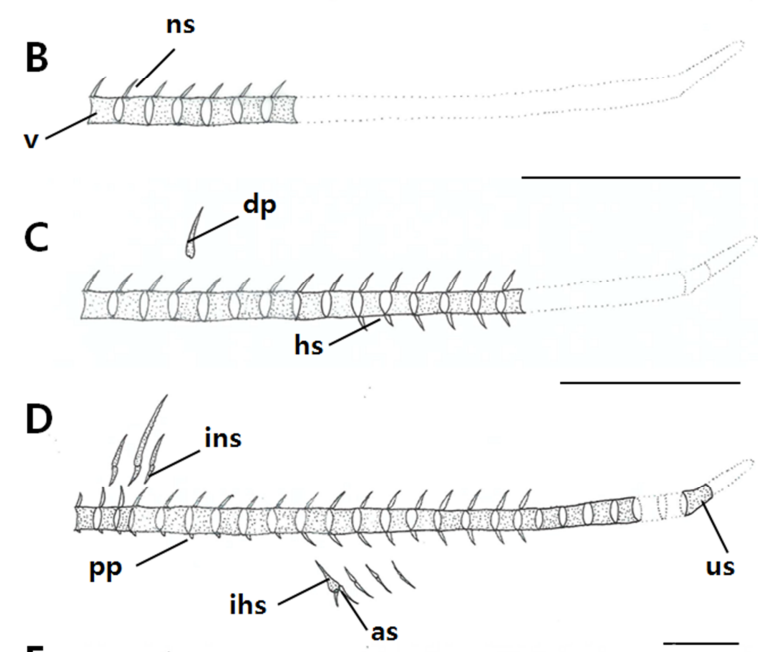

E

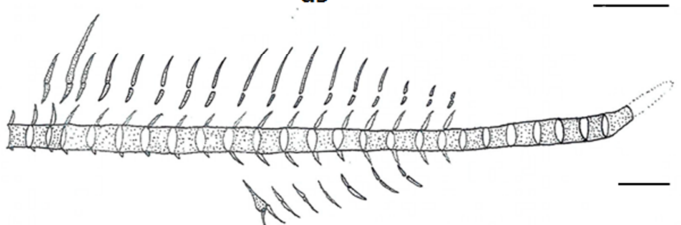

$\mathbf{F}$

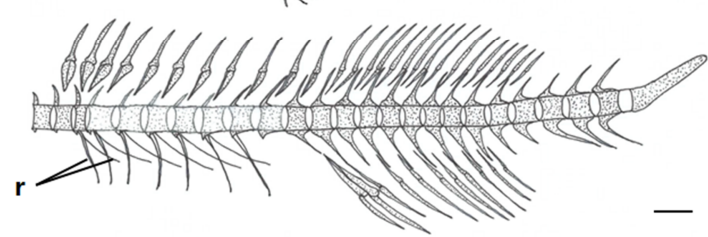

Fig. 4. Development of the vertebrae and spinous and soft fins in red spotted grouper, Epinephelus akaara. (A) $2.25 \mathrm{~mm}$ in Body length (BL); (B) $2.49 \mathrm{~mm}$ in $\mathrm{BL}$; (C) $3.44 \mathrm{~mm}$ in $\mathrm{BL}$; (D) $3.98 \mathrm{~mm}$ in BL; (E) $18.5 \mathrm{~mm}$ in BL; (F) $20.9 \mathrm{~mm}$ in BL. as, anal spine; dp, dorsal spine; hs, hemal spine; ihs, interhemal spine; ins, interneural ns, neural spine; pp, parapophysis; r, rib; us, urostyle; v, vertebrae column. Scale bars $=0.5 \mathrm{~mm}$.

ventral fin on the $15^{\text {th }}$ day after hatching, when average (BL) was $3.98 \mathrm{~mm}$. Of these two rays, the first ray grew long; then, on the $46^{\text {th }}$ day after hatching, when average (BL) was $20.9 \mathrm{~mm}$, this first ray shortened and the fish's form resembled that of an adult fish. The anal fin completed its development on the $46^{\text {th }}$ day after hatching, at an average (BL) of $20.9 \mathrm{~mm}$, with the appearance of 3 spines and 8 rays. Ossification of the pterygiophores began on the
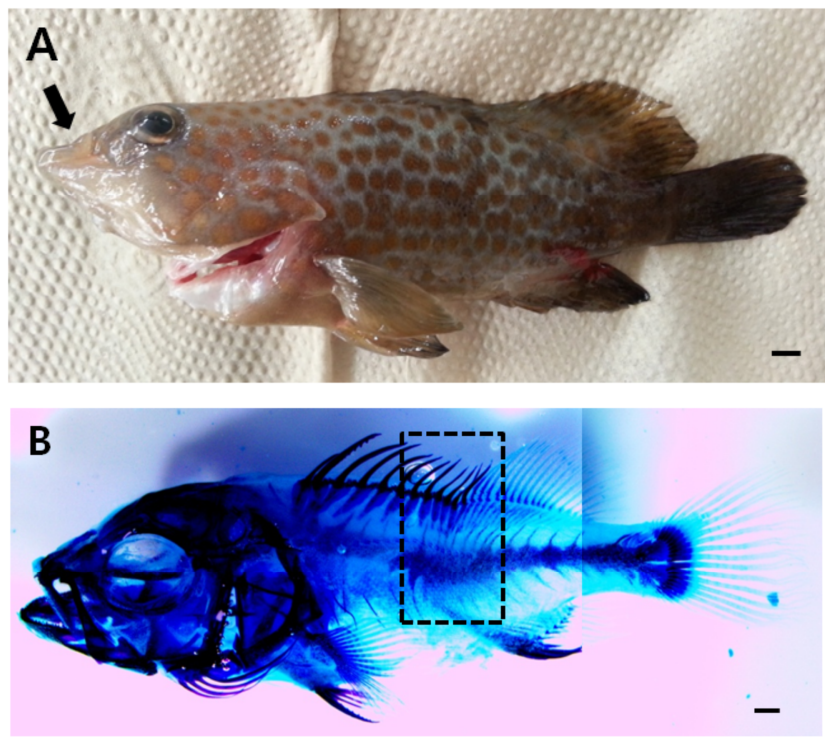

Fig. 5. Skeletal deformities in hatchery-reared red spotted grouper, Epinephelus akaara. (A) The maxillary and premaxilla bones have developed in a retracted state. (B) The vertebra, pterygiophore, and fin ray have developed in a bent state. Scale bars $=1.0 \mathrm{~mm}$.

$15^{\text {th }}$ day after hatching, at an average (BL) of $3.98 \mathrm{~mm}$, with the neural spine joining with the dorsal fin spine and the hemal spine joining with two spines on the anal fin. Ossification of the neural and hemal spines was completed by the $46^{\text {th }}$ day after hatching, when the average (BL) was $20.9 \mathrm{~mm}$.

\section{DISCUSSION}

Generally, bony fishes show noteworthy changes in osteological development at the time of hatching (Koumoundouros et al., 2001b). The progression of osteological development occurs prior to hatching, while the cranium and fins develop after hatching. Salmonid fishes begin their osteological development of the cranium and fins prior to hatching, whereas in perciformes, development of the cranium and fins occurs after hatching. Osteological development of red spotted grouper follows the latter pattern (Matsuoka, 1985; Koumoundouros et al., 1997b, 2001a, b; Faustion \& Power, 1999; Sfakianakis et al., 2004, 2005; Coban et al., 2009). 
Early Osteological Development of Larvae and Juveniles in Red Spotted Grouper, Epinephelus akaara (Pisces: Serranidae)

Table 3. Development process of the vertebrae in red spotted grouper, Epinephelus akaara

\begin{tabular}{|c|c|c|c|c|c|c|c|c|c|c|c|}
\hline \multirow{2}{*}{$\begin{array}{c}\text { Skeletal } \\
\text { elements }\end{array}$} & \multicolumn{11}{|c|}{ Body length (mm) } \\
\hline & 2.49 & 3.44 & 3.98 & 4.83 & 5.22 & 8.84 & 10.2 & 12.8 & 14.9 & 18.5 & 20.9 \\
\hline \multicolumn{12}{|l|}{ Vertebrae } \\
\hline \multicolumn{12}{|l|}{ Neural spine } \\
\hline \multicolumn{12}{|l|}{ Vertebral column } \\
\hline \multicolumn{12}{|l|}{ Abdominal vertebra } \\
\hline \multicolumn{12}{|l|}{ Hemal spine } \\
\hline \multicolumn{12}{|l|}{ Interhemal spine } \\
\hline \multicolumn{12}{|l|}{ Interneural spine } \\
\hline \multicolumn{12}{|l|}{ Dorsal spine } \\
\hline \multicolumn{12}{|l|}{ Anal spine } \\
\hline \multicolumn{12}{|l|}{ Caudal vertebra } \\
\hline \multicolumn{12}{|l|}{ Paraphophysis } \\
\hline Rib & & & & & & & & & & & \\
\hline
\end{tabular}

The red spotted grouper undergoes ossification of the cleithrum of the initial shoulder girdle and the parasphenoid bone that forms the base of the cranium, followed by ossification of the preopercle and opercle in the operculum. The spotted sea bass (L. maculatus; Kang et al., 2012) undergoes ossification of the cleithrum first, followed by ossification of parasphenoid, premaxillary, and dentary bones in the cranial region, while the Korean rockfish (Sebastes koreanus; Park et al., 2015a) undergoes ossification of the parasphenoid, frontal, supraoccipital, and epiotic bones in the cranial region first. The golden mandarin fish (S. scherzeri; Myoung et al., 2001) undergoes ossification of the parasphenoid and cleithrum first, followed by hyomandibular bone among the visceral skeleton and the preopercle and opercle in the operculum, whereas the panther puffer (Takifugu pardalis; Han et al., 2005) undergoes simultaneous ossification of the cleithrum, parasphenoid, and dentary bones. Scorpion fish (Sebastiscus marmoratus; Kim et al., 1997) and yellowbarred red rockfish
(S. tertius; Han et al., 2001) undergo simultaneous ossification of the cleithrum, jaw bone, and the parasphenoid, while the stellar rockskipper (Entomacrodus stellifer; Kim et al., 1992a) undergoes ossification of the cleithrum and parasphenoid first, then the jaw bone. The oblong rockfish (Sebastes oblongus; Byun et al., 2012) undergoes ossification of the cleithrum first, then the premaxillary and parietal bones. These data clearly show that there are interspecific differences among fishes.

In red spotted grouper, a single hole is formed in the scapula, which is one of the skeletal structures that support the pectoral fin, a typical trait among perciformes (Koumoundouros et al., 2001b; Park et al., 2015b). Fish species in which a hole forms in the scapula include perciformes, such as convict grouper (E. septemfasciatus; Park et al., 2015b), red seabream (Pagrus major; Matsuoka, 1987), crimson seabream (Dentex tumifrons; Koumoundouros et al., 2001a), and spotted sea bass (Kang et al., 2012), as well as scorpaeniformes, 
such as yellowbarred red rockfish (Han et al., 2001), scorpion fish (Kim et al., 1997), black rockfish (Sebastes schlegeli; Kim \& Han, 1991), and Korean rockfish (Park et al., 2015a). This trait also appears in other phylogenetic groups, including beloniformes, narrow tongue flyingfish (Cheilopogon heterurus; Dasilao \& Yamaoka, 1998); tetraodontiformes (Balistes capriscus; Matsuura \& Katsuragawa, 1984); and freshwater cypriniformes including Korean spined bittering (Acanthorhodeus gracilis; Kim \& Kim, 1998). Therefore, the formation of a hole in the scapula is not exclusive to perciformes.

The operculum of red spotted grouper underwent ossification of the preopercle and opercle at the same time, followed by ossification of the interopercle and subopercle. This pattern of osteological development is consistent with yellowbarred red rockfish (Han et al., 2001), scorpion fish (Kim et al., 1997), black rockfish (Kim and Han, 1991), and darkbanded rockfish (Kim et al., 1993) among scorpaeniformes. Moreover, the same pattern was apparent in other fish species, such as golden mandarin fish (Myoung et al., 2001), spotted sea bass (Kang et al., 2012), narrow tongue flyingfish (Dasilao \& Yamaoka, 1998), red seabream (Matsuoka, 1987), flathead goby (Luciogobius guttatus; Kim et al., 1992b), and greater amberjack (Seriola dumerili; Liu, 2001).

The Korean rockfish undergoes ossification of the preopercle first, then the opercle(Park et al., 2015a). In contrast, ossification in shad fish (Ilisha elongate; Han et al., 2000) occurs first in the opercle, then the interopercle, then the preopercle. These data indicate that there are interspecific differences in osteological development of the operculum among fishes.

The vertebra of red spotted grouper begins ossification with the formation of 7 centra at an average body length of $2.49 \mathrm{~mm}$. Ossification progresses in the direction of the caudal vertebra in the abdominal vertebra. This tendency also appears in shad fish (Han et al., 2000), Japanese halfbeak (Lee et al., 2001), mackerel pike (Cololabis saira; Fujita \& Oozeki, 1994), and panther puffer (Han et al., 2005). Therefore, the direction of the ossification of centra does not vary significantly between fish species.

Before all of the centra had completed the ossification process in red spotted grouper, ossification of the urostyle began, a pattern that was also seen in oblong rockfish (Byun et al., 2012), grass puffer (Takifugu niphobles; Fujita, 1992), mackerel pike (Fujita \& Oozeki, 1994), shad fish (Han et al., 2000), and spotted sea bass (Kang et al., 2012). In contrast, convict grouper (Park et al., 2015b) and golden mandarin fish (Myoung et al., 2001) showed a different pattern in which ossification of the urostyle was completed only after ossification of all centra was complete.

In red spotted grouper, the neural spine developed as ossification of the centra progressed; subsequently, development of the hemal spine occurred. In contrast, Korean rockfish (Park et al., 2015a), oblong rockfish (Byun et al., 2012), mackerel pike (Fujita \& Oozeki, 1994), and grass puffer (Fujita, 1992) completed ossification of the neural and hemal spines before ossification of the centra had completed.

Regarding fin development in perciformes, the posterior dorsal fin and anal fin generally develop before the anterior dorsal fin develops (Johnson, 1984; Faustino \& Power, 1999). Red spotted grouper showed a development pattern typical of perciformes, in which the pterygiophores, which support the fins, developed after ossification of dorsal fin had begun. Ossification progressed in a characteristic anterior to posterior direction. Moreover, just as in common carp (Cyprinus carpio Itazawa, 1963), red seabream (Kohno et al., 1983), and northern snakehead (Channa argus; Itazawa, 1963), ossification of pterygiophores in red spotted grouper occurred later than ossification of the vertebra and fin rays. At this stage, ossification of the vertebra and fin rays had been completed for the most part. This ossification appears to play a role in increasing momentum when the fish swims (Lee et al., 2001).

On the $15^{\text {th }}$ day after hatching, red spotted grouper showed the characteristic developmental progression in which the 
second spine on the dorsal fin and the first spine on the ventral fin grew longer than did the other fin rays, later shortening again by the $46^{\text {th }}$ day after hatching. This phenomenon appears in fishes belonging to Serranidae family, including convict grouper (Park et al., 2015b), longtooth grouper (Epinephelus bruneus; Song et al., 2005), and spotlined bass (Liopropoma japonicum; Kim et al., 2004).

The caudal skeleton, which supports the anal fin, is made up of a caudal complex consisting of vertebrae and bone fragments. When individuals reached an average (BL) of $2.25 \mathrm{~mm}$, red spotted grouper presented a urostyle with a curvature of $45^{\circ}$. At an average (BL) of $3.98 \mathrm{~mm}$, ossification of the urostyle began, and at an average (BL) of $20.9 \mathrm{~mm}$, ossification of the centra and urostyle was complete. This developmental progression may be seen in most bony fishes. Ossification of the urostyle was completed in convict grouper (Park et al., 2015b), oblong rockfish (Byun et al., 2012), yellowbarred red rockfish (Han et al., 2001), scorpion fish (Kim et al., 1997), and darkbanded rockfish (Kim et al., 1993) before ossification of the tail area was complete, whereas ossification of the urostyle began in black rockfish (Kim \& Han, 1991) after ossification of the centra had been completed. These data represents a noteworthy difference between fishes.

The union of the hypural bones provides very important basic data for phylogenetic systematics studies. Red spotted grouper gives the appearance of 2 hypural bones $(1+2+3$, $4+5$ ), while convict grouper (Park et al., 2015b), which belongs to the same Serranidae family, has 3 hypural bones $(1+2,3,4+5)$. Japanese halfbeak (Lee et al., 2001) shows a union of 3 hypural bones $(1+2,3+4,5)$, along with oblong rockfish (Byun et al., 2012), darkbanded rockfish (Kim et al., 1993), black rockfish (Kim \& Han, 1991), and yellowbarred red rockfish (Han et al., 2001). Meanwhile, the Carangidae family of fishes (Kohno, 1997; Liu, 2001) shows a union of 2 hypural bones $(1+2,3+4+5)$. Therefore, various forms of bone union are seen among different fish species.

Observation of the osteological development process in fish larvae and juveniles is very important because it can aid in identifying the sources of skeletal deformities in fishes. Close scrutiny of each skeletal region during the rearing period is necessary. Deformities in red spotted groupers were seen in the vertebrae, pterygiophores, and fin rays, and some hatchery-reared juvenile specimens showed deformities in the maxilla and premaxilla (Fig. 5). In the Serranidae family of fishes, deformities in the form of curved premaxilla and vertebra occurred in dusky grouper (Epinephelus marginatus; Boglione et al., 2009) during the postlarval stage, as well as deformities in the maxilla and caudal skeleton. Meanwhile, deformities in the convict grouper (Nagano et al., 2007) included the premaxilla and maxilla being retracted relative to the dentary bones and the area between the abdominal and caudal vertebrae being curved. Various deformities were noted in Pleuronectidae, including Atlantic halibut (Hippoglossus hippoglossus; Lewis \& Lall, 2006), which had deformities in the abdominal vertebra, caudal vertebra, neural spine, and hemal spine. Therefore, in order to identify the causes of deformities in hatchery-reared fishes with in case of this study, it is necessary to carefully study the rearing of fish larvae and juveniles in hatcheries, including the care of female fish, feed, and the water environment.

\section{SUMMARY}

In the present study, we observed the osteological development of red spotted grouper (Epinephelus akaara) larvae and juveniles in order to gather basic data on deformities and inform phylogenetic systematics research. Larvae and juveniles were obtained from an indoor hatchery in Muangun, South Jeolla Province, Korea. The temperature range during cultivation was $21.5 \sim 24.5^{\circ} \mathrm{C}$ (mean $23.0 \pm 1.5^{\circ} \mathrm{C}$ ), and salinity was $32.5 \sim 33.5$ psu (mean 33.0 psu). Newly 
hatched fish larvae had not undergone any ossification, but ossification of the parasphenoid bone, which forms the base of the cranium, occurred as the juveniles reached an average (BL) of $2.49 \mathrm{~mm}$. In addition, ossification of the preopercle and opercle occurred in the operculum, and ossification of the maxilla, which forms the upper jaw, and the dentary bones, which form the lower jaw, began. Next, ossification of the vertebra occurred by formation of 7 vertebral centra and the neural spine in the abdominal vertebra. When the juveniles reached an average (BL) of $5.22 \mathrm{~mm}$, ossification of the nasal, lateral ethmoid, and alisphenoid bones occurred in the cranium, while ossification of the endopterygoid and metapterygoid bones began in the palatine region, and ossification of the hypohyal and interhyal bones occurred in the hyoid arch. When the fish reached an average (BL) of $20.9 \mathrm{~mm}$, ossification of the basisphenoid bone in the cranium and the suborbital bone in the orbital region occurred. Moreover, ossification of the vertebra underwent formation of long pairs of 7 ribs from the third to the ninth abdominal vertebrae, which completed the osteological development process.

\section{ACKNOWLEDGEMENT}

This research was supported by the project of National Institute of Fisheries Science (NIFS), Republic of Korea (R2016017).

\section{REFERENCES}

Boglione C, Marino G, Giganti M, Longobardi A, Marzi PD, Cataudella S (2009) Skeletal anomalies in dusky grouper Epinephelus marginatus (Lowe 1834) juveniles reared with different methodologies and larval densities. Aquaculture 291:48-60.

Byun SG, Kang CB, Myoung JG, Cha BS, Han KH, Jung CG (2012) Early osteological development of the larvae and juveniles in Sebastes oblongus (Pisces: Scorpaenidae). Korean J Ichthyol 24:67-76. (in Korean)

Coban D, Suzer C, Kamaci HO, Saka S, Firat K (2009) Early osteological development of the fins in the hatcheryreared red porgy, Pagrus pagrus (L. 1758). J Appl Ichthyol 25:26-32.

Dasilao Jr JC, Yamaoka K (1998) Osteological and functional development of the flyingfish, Cypselurus heterurus doederleini (Teleostei: Exocoetidae). Bull Mar Sci Fish Kochi Univ 18:13-26.

Faustino M, Power DM (1999) Development of the pectoral, pelvic, dorsal and anal fins in cultured sea bream. J Fish Biol 54:1094-1110.

Fujita K (1992) Development of the caudal skeleton in the tetraodontid fish, Takifugu niphobles. Japan J Ichthyol $38: 438-440$.

Fujita K, Oozeki Y (1994) Development of the caudal skeleton in the saury, Cololabis saira. Japan J Ichthyol 41:334337.

Han KH, Cho JK, Lee SH, Hwang SY, Yoon SM, Seo WI, Kim CC (2005) Osteological development of the larvae and juveniles of Takifugu pardalis (Teleostei: Tetraodontodae). Korean J Ichthyol 17:29-35. (in Korean)

Han KH, Kim DY, Noh BY, Oh SH, Kim YM, Jin DS, Kim YU (2000) Morphological and skeletal development of the larvae and juveniles of the slender, Ilisha elongata (Bennett) (Teleostei: Clupeidae). Korean J Ichthyol 12:230-235. (in Korean)

Han KH, Lim SK, Kim KS, Kim CW, Yoo DJ (2001) Osteological development of the larvae and juveniles of Sebasticus tertius (Barsukov et Chen) in Korea. Korean J Ichthyol 13:63-68. (in Korean)

Itazawa Y (1963) The ossification sequences of the vertebral column in the carp and snakehead fish. Bull Jap Soc Sci Fish 29:667-674.

Johnson GD (1984) Percoidei: development and relationships. In: Moser HG, Richards WJ, Cohen DM, Fahay 
Early Osteological Development of Larvae and Juveniles in Red Spotted Grouper, Epinephelus akaara (Pisces: Serranidae)

MP, Kendall AW, Richardson SL (eds). Ontogeny and Systematics of Fishes. Lawrence, KS: Allen Press Inc, pp464-498.

Kang CB, Myoung JG, Kim YU, Kim HC (2012) Early osteological development and squamation in the spotted sea bass Lateolabrax maculates (Pisces: Lateolabracidae). Korean J Fish Aquat Sci 45:271-282. (in Korean)

Kim IS, Choi Y, Lee CL, Lee YJ, Kim BJ, Kim JH (2005) Illustrated Book of Korean Fishes. Seoul: Kyo-Hak Publishing, 276-286. (in Korean)

Kim IS, Kim IJ (1998) Study on osteological characteristics of Acanthorhodeus gracilis. Korean J Ichthyol 10:231-240. (in Korean)

Kim S, Yoo JM, Lee EK (2004) Description of a postflexion larva specimen of Liopropoma japonicum (Doderlein) off Jeju Island, Korea. Ocean and Polar Res 26:685688. (in Korean)

Kim YU, Han KH (1991) The early life history of rockfish Sebastes schlegeli. Korean J Ichthyol 3:67-83. (in Korean)

Kim YU, Han KH, Byun SK (1993) The early life history of the rockfish, Sebastes inermis 2. Morphological and skeletal development of larvae and juveniles. Bull Korean Fish Soc 26:465-476. (in Korean)

Kim YU, Han KH, Kang CB (1992a) Morphology and skeletal development of larvae and juveniles of Entomacrodus stellifer lighti (Herre). Korean J Ichthyol 4:31-43. (in Korean)

Kim YU, Han KH, Kang CB, Kim JK, Byun SK (1997) The early life history of the rockfish, Sebastiscus marmoratus 2. Morphology and skeletal development of larvae and juvenile. Korean J Ichthyol 9:186-194. (in Korean)

Kim YU, Han KH, Kang CB, Ryu JW (1992b) Early life history and spawning behavior of the gobiid fish, Luciogobius guttatus Gill. Korean J Ichthyol 4:1-13. (in Korean)

Kohno H (1997) Osteological development of the caudal skeleton in the carangid, Seriola lalandi. Ichthyol Res
$44: 219-221$.

Kohno H, Taki Y, Ogasawara Y, Shirojo Y, Taketomi M, Inoue M (1983) Development of swimming and feeding function in larval Pagrus major. Japan J Ichthyol, 30(1): 47-60.

Koumoundouros G, Divanach P, Kentouri M (1999) Osteological development of the vertebral column and of the caudal complex in Dentex dentex. J Fish Bio 54:424436.

Koumoundouros G, Divanach P, Kentouri M (2001a) Osteological development of Dentex dentex (Osteichthyes: Sparidae): dorsal, anal, paired fins and squamation. Mar Biol 38:399-406.

Koumoundouros G, Gagliardi F, Divanach P, Boglione C, Cataudella S, Kentouri M (1997a) Normal and abnormal osteological development of caudal fin in Sparus aurata L. fry. Aquaculture 149:215-226.

Koumoundouros G, Oran G, Divanach P, Stefanakis S, Kentouri M (1997b) The opercular complex deformity in intensive gilthead sea bream (Spartus aurata L.) larviculture. Moment of apparition and description. Aquaculture 156:165-177.

Koumoundouros G, Sfakianakis DG, Maingot E, Divanach P, Kentouri M (2001b) Osteological development of the vertebral column and of the fins in Diplodus sargus (Teleostei: Perciformes: Sparidae). Mar Bio 139:853862.

Lee CK, Hur SB (1997) Yolk resorption, onset of feeding and survival potential of larvae of red spotted grouper, Epinephelus akaara. J Aquaculture 10:473-483. (in Korean)

Lee CK, Hur SB (1998) Effect of live food and water temperature on larval survival of red spotted grouper, Epinephelus akaara. J Aquaculture 11:565-572. (in Korean)

Lee CK, Hur SB, Ko TS, Park S (1998) Maturation, sex ratio and sex-reversal of red spotted grouper, Epinephelus 
akaara. J Aquaculture 11:573-580. (in Korean)

Lee CK, Hur SB, Park S, Kim BG (1997) Qualities of spawned eggs during the spawning period in red spotted grouper, Epinephelus akaara. J Aquaculture 10:463472. (in Korean)

Lee SJ, Kim YU, Han KH (2001) Ostelogical development of larvae and juveniles of Hyporhampus sajori (Teleostei: Hemiramphidae). Korean J Ichthyol 13:173-180. (in Korean)

Lewis LM, Lall SP (2006) Development of the axial skeleton and skeletal abnormalities of atlantic halibut (Hippoglossus hippoglossus) from first feeding through metamorphosis. Aquaculture 257:124-135.

Liu CH (2001) Early osteological development of the yellow tail Seriola dumerili (Pisces: Carangidae). Zool Stud 40:289-298.

Matsuoka M (1985) Osteological development in the red sea bream, Pagrus major. Japan J Ichthyol 32:35-51.

Matsuoka M (1987) Development of the skeletal tissues and skeletal muscles in the red sea bream. Bull Seikai Red Fish Res Lab 65:1-14.

Matsuura Y, Katsuragawa M (1984) Osteological development of fins and their supports of larval grey triggerfish, Balistes capriscus. Japan J Ichthyol 31:411-421.

Myoung JG, Mun JH, Kim JK, Park KD, Kang CB, Kim YU, Park JT (2001) Osteological development of larvae and juveniles of Korean mandarin fish, Siniperca scherzeri (Perciformes, Centropomidae). Korean J Ichthyol 13: 129-135. (in Korean)

Nagano N, Hozawa A, Fujiki W, Yamada T, Miyaki K, Sakakura Y, Hagiwara A (2007) Skeletal development and deformities in cultured larval and juvenile sevenband grouper, Epinephelus septemfasciatus (Thunberg). Aquaculture Res 38:121-130.

Park JM, Cho JK, Han H, Han KH (2015a) Morphological and skeletal development and larvae and juvenile of
Sebastes koreanus (Pisces: Scorpaenidae). Korean J Ichthyol 27:1-9. (in Korean)

Park JM, Cho JK, Han KH, Kim NR, Hwang HK, Kim KM, Myeong JI, Son MH (2014) Early life history of the sevenband grouper, Epinephelus septemfasciatus from Korea. Dev Reprod 18:13-23. (in Korean)

Park JY, Cho JK, Son MH, Kim KM, Han KH, Park JM (2016a) Artificial spawning behavior and development of eggs, larvae and juveniles of the red spotted grouper, Epinephelus akaara in Korea. Dev Reprod 20:31-40. (in Korean)

Park JY, Hong CG, Cho JK, Son MH, Han KH, Park JM (2015b) Early osteological development of the larvae and juveniles in sevenband grouper, Epinephelus septemfasciatus (Pisces: Serranidae). Korean J Ichthyol 27:189-198. (in Korean)

Park JY, Kim NR, Park JM, Myeong JI, Cho JK (2016b) The structure of digestive tract and histological features of the larvae in sevenband grouper, Epinephelus septemfasciatus. Korean J Ichthyol 28:9-18. (in Korean)

Park JY, Park JM, Hong CG, Kim KM, Cho JK (2016c) Physiological and biochemical response of blood on low temperature stress in sevenband grouper, Epinephelus septemfasciatus. Korean J Ichthyol 28:1-8. (in Korean)

Sfakianakis DG, Doxa CK, Kouttouki S, Koumoundouros G, Maingot E, Divanach P, Kentouri M (2005) Osteological development of the vertebral column and of the fins in Diplodus puntazzo (Cetti, 1777). Aquaculture 250:36-46.

Sfakianakis DG, Koumoundouros G, Divanach P, Kentouri M (2004) Osteological development of the vertebral column and of the fins in Pagellus erythrinus (L. 1758). Temperature effect on the developmental plasticity and morpho-anatomical abnormalities. Aquaculture 232:407424.

Song YB, Oh SR, Seo JP, Ji BG, Lim BS, Lee YD, Kim HB (2005) Larval development and rearing of longtooth 
grouper Epinephelus bruneus in Jeju Island, Korea. J

World Aquaculture Soc 36:209-216.

Ukawa M, Higuchi M (1966) Spawning habits and early life history of a serranid fish, Epinephelus akaara.
Japan J Ichthyol 13:156-161.

Walker MB, Kimmel CB (2007) A two-color acid-free cartilage and bone stain for zebrafish larvae. Biotechnic \& Histochemistry 82:23-28. 